Journal of

Arid

Environments

\title{
Airborne dust accumulation and soil development in the North-East sector of Gran Canaria (Canary Islands, Spain)
}

\author{
I. Menéndez ${ }^{\mathrm{a}, *}$, J.L. Díaz-Hernández ${ }^{\mathrm{b}}$, J. Mangas ${ }^{\mathrm{a}}$, \\ I. Alonso ${ }^{\mathrm{a}}$, P.J. Sánchez-Soto ${ }^{\mathrm{c}}$
}

${ }^{a}$ Physics Department, Las Palmas de Gran Canaria University, Campus de Tafira, 35017, The Canary Islands, Spain

${ }^{\mathrm{b}}$ Centro de Investigaciones Agrarias, Junta de Andalucia, Camino del Purchil, s/n., Granada, Spain

${ }^{\mathrm{c}}$ Instituto de Ciencia de los Materiales CSIC-US, c/ Américo Vespucio sn., 41092, Sevilla, Spain

Received 31 January 2006; received in revised form 27 October 2006; accepted 7 March 2007

Available online 25 April 2007

\begin{abstract}
The island of Gran Canaria is located in the eastern Atlantic, to the west of the Saharan Desert, and, as a result of its proximity, is regularly affected by Saharan dust. When this weather condition occurs (haze conditions) the particulate/aerosol accumulation rate was lightly higher than under nonhaze conditions $\left(5.4 \pm 3.8 \mathrm{mg} \mathrm{m}^{-2} \mathrm{~h}^{-1}\right.$ versus $\left.4.3 \pm 2.1 \mathrm{mg} \mathrm{m}^{-2} \mathrm{~h}^{-1}\right)$. To quantify the contribution of airborne Saharan dust to soil development in northeastern Gran Canaria, aeolian dust was collected weekly at different altitudes and distances from the coast during a year in a series of collection plots. Mean values of dust accumulation rates decreased with increasing altitude (from 79 to $17 \mathrm{~g} \mathrm{~m}^{-2} \mathrm{yr}^{-1}$ ). The mineralogy of airborne dust, identified by XRD, was quartz, Mg-calcite, calcite, feldspars, dolomite, magnetite, aragonite, halite, and minor amounts of illite, kaolinite-chlorite and palygorskite. Quartz is considered allochthonous because it is not present in the volcanic substrate of the island. However, the difference in quartz concentration from haze to non-haze conditions was only $10 \%$ higher. This suggests an external source, but does not preclude a recycled origin. The recognition of well shaped dolomites, observed by SEM-EDX in collected dust samples and in soils samples of the lowest altitude plot, indicate an edaphic origin, but are later recycled as an airborne component.
\end{abstract}

(C) 2007 Elsevier Ltd. All rights reserved.

Keywords: Dolomites; Dust mineralogy; Haze; Quartz; Saharan aerosol

\footnotetext{
*Corresponding author. Tel.: + 34928452922 .

E-mail address: imenendez@dfis.ulpgc.es (I. Menéndez).
} 


\section{Introduction}

Investigations of dust storm along with dust properties are relevant to the global climate change studies due to the role of dust in a number of important processes. Desert dust could affect climate through direct effect by absorbing and reflecting solar radiation and indirectly by modifying cloud properties. Both effects could contribute to the variation of the earth's radiation budget (Dentener et al., 1996; Ramanathan et al., 2001), and the degree of these effects is determined by chemical, physical and mineralogical properties of dust particles.

Wind erosion is a serious problem in many parts of the world especially in arid and semiarid regions. It physically removes the most fertile portion of soil (Stoorvogel et al., 1997). Soil particles from damaged land enter suspension and become part of the atmospheric dust load. Dust obscures visibility and pollutes the air, causes accidents, fouls machinery, and affect animal and human health (Griffin et al., 2001). Aeolian sediments also pollute water bodies and cause associated problems.

On the other hand, desert dust is a source of plant nutrients, in particular micronutrient iron that is a limiting element for the growth of phytoplankton in the surface waters of several large open ocean regions. Recent iron fertilization experiments in the ocean provide strong evidence on the important role of iron in regulating phytoplankton growth (Zhu et al., 1997). Therefore the input of aeolian iron to the ocean may regulate the ocean carbon cycles and then global climate.

Airborne dust from the Sahara desert has a significant effect on adjacent and also global scale (Herrmann et al., 1996; Loÿe-Pilot and Martin, 1996; Prospero, 1996; Yaloon, 1987). For example, Herrmann et al. (1996) showed that the amounts of airborne dust in edaphic material ranged from $4 \%$ to $66 \%$ for perisaharan soils depending on the distance from the sources, the climate and the age of the soils. Calima (haze) is one local Canarian name for the meteorological condition by which Saharan dust is transported by wind. According to Criado and Dorta (2003), Saharan dust is an usual particulate input in Canary Island soils and has an important weight on the annual mean dust deposition (Dorta et al., 2002). The dust sources in the island of Gran Canaria can be autochthonous (particles of diverse origin generated and/or recycled within the insular area) and allochthonous (from the neighboring African continent and transported during haze conditions). The Saharan Desert generates a wide variety of particles owing to the range of different origin (magmatic, sedimentary and metamorphic) and ages (Precambrian to recent) present in Northwest Africa (Piqué, 2001). The source areas of the dust components were established, by data from the Total Ozone Mapping Spectrometer (TOMS), to be in two major areas: the Bodélé depression (Southern of Chad) and the Eastern Mauritania-Western MaliSouthern Algeria area (Goudie and Middleton, 2001).

This Saharan dust arrives to Canary Islands in two main ways (Pérez-Marrero et al., 2002): firstly, as large plumes due to the development of unstable east-wind waves over an extended high pressure system, or as a result of the presence of smooth gradients of atmospheric turbidity spread along the African coast, associated with the displacement of the African thermal low pressures towards the coast and the reduced influence of the Azores High. The latter situation is more frequent in summer.

Usually airborne dust quantification has been measured either volumetrically (Herrmann et al., 1996; Molinaroli et al., 1999) or through accumulation rates (Cattle et al., 2002; Criado and Dorta, 2003; Díaz-Hernández and Miranda, 1997; Rabenhorst 
et al., 1984). We have considered in this study accumulation rate. Otherwise, accumulation rate instead of deposition rate (Goossens and Offer, 1994) is considered a more realistic term that implies a balance between deposition and erosion rates (Goossens, 2001). Other authors use the stabilization concept, understood as the proportion of dust which becomes an input to local soil profiles (Cattle et al., 2002), as it takes into consideration that dust accumulation can be overestimated with respect to the stabilized dust in the soils (about $50 \%$, Mc Tainsh, 1980).

Soils on Gran Canaria show carbonate levels usually present between 0 and $300 \mathrm{~m}$ above sea level (m a.s.l.; Sánchez, 1975). The formation of these carbonate horizons in arid and semiarid soils may be related to weathering of the volcanic substrate (Alonso-Zarza and Silva, 2002; Jahn et al., 1985; Treadwell-Steitz and Mc Fadden, 2000); accumulation and alteration of particles from marine carbonate deposits in some coastal soils (Naiman et al., 2000); and dust accumulation and its alteration (Capo and Chadwick, 1999; Hamidi et al., 2001; Kleber, 2000; Sánchez, 1975). All these potential of carbonate sources could be applied to soils on Gran Canaria.

The silica subsaturated nature of potential protoliths in the Canary Islands (Carracedo et al., 2002; Vera, 2004), characteristic of an oceanic island volcanic setting, precludes the widespread presence quartz in the paragenesis of the underlying rocks. The Canary Islands show mostly silica subsaturated volcanic rocks. However, in the island of Gran Canaria silica saturate rocks are present in the form of rhyolitic rocks associated with the Mogan Formation (ITGE, 1992; Schmincke, 1993) and residual amounts of microcrystalline silica (agate-chalcedony-moganite; Götze et al., 1998). In addition, quartz particles have been detected in sediments collected in the Canary Islands, with this mineral assumed to be of Saharan origin (Alcántara-Carrió, 2003; Fernandez-Caldas et al., 1982; Criado and Dorta, 2003; Mizota and Matsuhisa, 1995).

The aim of this paper is to quantify and analyze the airborne dust as a textural and mineralogical component of the soils on Gran Canaria, under consideration of meteorological conditions and altitudinal variability. Otherwise, it represents the first study of ambient dust in the Canary Islands from the perspective of dust accumulation in non-haze condition.

\section{Methodology}

\subsection{Meteorological conditions and description of the studied area}

The island of Gran Canaria is located approximately in the center of the Canary Island Archipelago (Fig. 1). It was a roughly circular topology with a diameter of around $45 \mathrm{~km}$, representing an area of $1560 \mathrm{~km}^{2}$. The highest point $(1949 \mathrm{~m}$, at Pico de Las Nieves) is situated to the SE of the center of the island, and gives rise to a dense radial network of strongly incised gullies. $56 \%$ of the island's surface has an average slope between $15^{\circ}$ and $30^{\circ}$ (Sánchez et al., 1995). Climatic differences between the north side (temperate and humid) and the south side (warm and dry) are caused both by the influence of trade winds (N-NW component) and by orographic control. The latter is expressed also as an altitudinal gradation in climatic conditions: arid-semiarid coastal areas $\left(<250 \mathrm{~mm} \mathrm{yr}^{-1}\right)$, temperate for mid-elevation areas $\left(250-800 \mathrm{~mm} \mathrm{yr}^{-1}\right)$, and moist and colder conditions for the summit areas $\left(>800 \mathrm{~mm} \mathrm{yr}^{-1}\right.$, Marzol, 1988). The former is evidenced by the predominance of wet and cloudy conditions in the northern sector of Gran Canaria. 

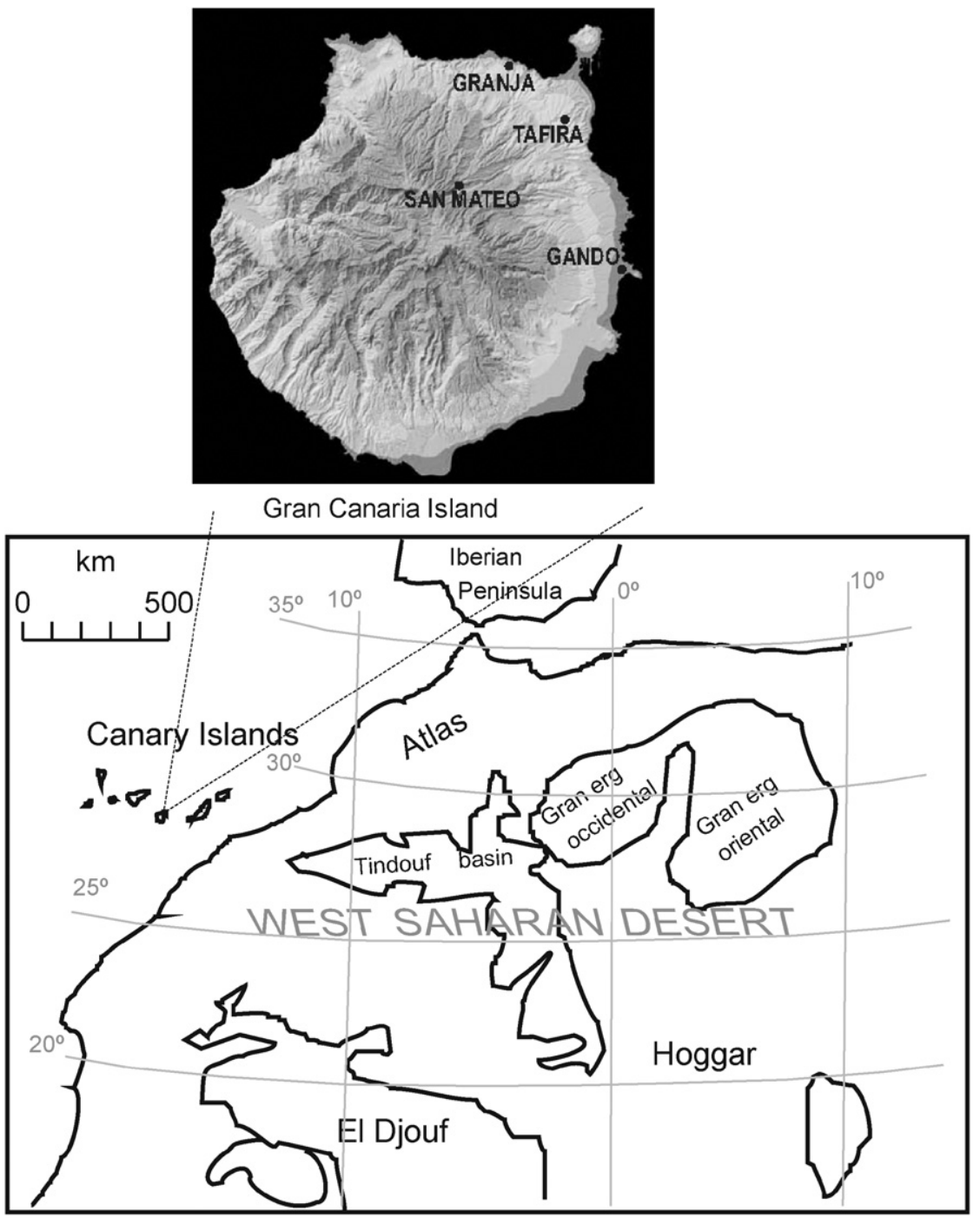

Fig. 1. Study site and dust trays locations across the Gran Canaria Island (Canary archipelago).

Average moisture and annual precipitation increase with altitude. In addition, the island's proximity to the West Saharan Desert results in the common presence of Saharan winds, (30\% of the year, for a 5-yr period, Sancho et al., 1992), which carry abundant aeolian dust. The rest of the year is dominated by trade winds, from a N-NE direction (Dorta et al., 2002). Tropical storm conditions, entering from the W-SW direction, occur occasionally and are related to high precipitation rates (Marzol, 1988).

The oldest subaerial volcanism on Gran Canaria is Miocene (from 14.5 to 14.1 Million years; McDougall and Schmincke, 1976) characterized by the extrusion of large volumes of basaltic rocks, and corresponds to the shield volcano stage of the construction of the island's volcanic edifice. In its waning stage, an episode of alkalic volcanism takes place 
between 14.1 and 7.0 million years, creating more differentiated, silica-undersaturated rocks (tephrites, phonolitic tephrites, trachytic-phonolites and trachytic-rhyolites). This is followed by a hiatus in volcanic activity between 7.0 and 5.5 million years that results in an erosional event and the deposition of the essentially sedimentary sequence of Las Palmas Detritic Formation. Finally, a volcanic rejuvenation stage from 5.5 million years to recent give rise to basaltic and differentiated rocks (Carracedo et al., 2002; ITGE, 1992; Vera, 2004).

The sampling sites were located in the N-NE quadrant of the island of Gran Canaria (Fig. 1): Gando (GA), Granja (GR), Tafira (TA) and San Mateo (SM), because they are representative of the island from both a meteorological and altitudinal point of view. The sampling locations were placed close to meteorological station. They represent an altitudinal gradient (Table 1), with different rainy conditions: plots GA and GR are drier than TA and SM.

Daily pluviometric data, visibility as well as wind strength and direction derived from the nearby meteorological stations were made availably by the local branch of the Instituto Nacional de Meteorologia in Las Palmas, located in Tafira, and by the Meteorological Station at La Granja, located in Arucas (Gran Canaria) and belonging to the Cabildo de Gran Canaria.

The underlying lithology of the sampling plots varied from basanite and phonolitic tephrite, and of this belonging to the latest volcanic rejuvenation stage (Table 1). These materials are covered by an aeolian mantle, on which Ochrept, Xerert and Udalf soils are developed (Table 1).

\subsection{Dust sampling design and soil samples collection}

There was decided to choose a dry flat surface as samplereds. Goossens and Offer (1994) evaluated the efficiency of 4 types of collectors: The dry flat surface (our case), a flat with a

Table 1

General features of the studied plots

\begin{tabular}{|c|c|c|c|c|c|c|c|c|c|}
\hline Code & Site & $\begin{array}{l}\text { Coordenantes } \\
(\text { UTM, 28R ...) }\end{array}$ & $\begin{array}{l}\text { Altitude } \\
\text { (m a.s.l.) }\end{array}$ & $\begin{array}{l}\operatorname{Rain}^{\mathrm{a}} \\
\mathrm{mm} \mathrm{yr}^{-1}\end{array}$ & Vegetation $^{\mathrm{b}}$ & Substrate type & $\begin{array}{l}\text { Basaltic } \\
\text { age } \\
\left(\times 10^{3} \mathrm{a}\right)\end{array}$ & $\begin{array}{l}\text { Soil type } \\
\text { (USDA) }^{\mathrm{f}}\end{array}$ & $\begin{array}{l}\text { Wheatering } \\
\text { products }^{\mathrm{f}}\end{array}$ \\
\hline GA & Gando & 4634003090000 & 10 & 100 & Xerofila & $\begin{array}{l}\text { Basalt and eolic } \\
\text { mantle }\end{array}$ & $2800-600^{\mathrm{c}}$ & Ochrept & Montmorill. \\
\hline GR & Granja & 4505003113100 & 53 & 150 & Xerofila & $\begin{array}{l}\text { Phonolitic } \\
\text { tephrite and eolic } \\
\text { mantle }\end{array}$ & $500^{\mathrm{d}}$ & Xerert & Montmorill. \\
\hline TA & Tafira & 4555503106500 & 280 & 300 & $\begin{array}{l}\text { Scrup/ } \\
\text { forest }\end{array}$ & $\begin{array}{l}\text { Basanite and } \\
\text { colluvion }\end{array}$ & $15^{\mathrm{e}}$ & Ochrept & Montmorill. \\
\hline SM & $\begin{array}{l}\text { San } \\
\text { Mateo }\end{array}$ & 4470003098525 & 945 & 700 & $\begin{array}{l}\text { Scrup/ } \\
\text { forest }\end{array}$ & Basalt & $5000-3500^{\mathrm{e}}$ & Udalf & Halloysite \\
\hline
\end{tabular}

\footnotetext{
${ }^{\mathrm{a}}$ Marzol, 1988.

${ }^{\mathrm{b}}$ Sanchez et al., 1995.

${ }^{\mathrm{c}}$ ITGE, 1992, K/Ar-ages.

${ }^{\mathrm{d}}$ Leitz and Schmincke, K/Ar-ages, 1975.

${ }^{\mathrm{e}}$ Hansen, 1993, K/Ar-ages.

${ }^{\mathrm{f}}$ Sanchez, 1975.
} 
moist surface, a surface composed of two superimposed layers of marbles, and a free water surface. These authors recommended the use of no water (or moist) collectors when chemical composition of the sediment deposited has to be determined. In our case, for mineralogical analysis, we preferred the simplest dry option. Even Goossens and Offer (1994) propose the standard use of marble beads in deposition or accumulation research, we decided not to include marbles in the bottom of the tray because we considered that dust collection was going to be much less effective. Since, in our case, in order to fully detach dust grains adhered to the collection surface, due to residual moisture, we needed to make use of a rubber spatula, to additionally include each an every marble on the collector in this procedure would be not only inefficient but would also increase the potential for contamination of the sample.

Following the experience of Díaz-Hernández and Miranda (1997), glass trays (Pirex ${ }^{\circledR}$ ) with an internal area of $0.097 \mathrm{~m}^{2}$ were placed at different positions, within the site depending on existing plot facilities: At GA two collection trays were placed on a building roof, one tray on the roof floor $\left(\mathrm{GA}_{\text {floor }}\right)$, on top of a glass surface $(60 \times 100 \mathrm{~cm})$ covered with a PVC mesh ( $2 \mathrm{~mm}$ mesh opening) in order to form a rough area that could trap the saltation particles (Fig. 2; Bauer et al., 2004; Owen, 1964). The other tray was affixed on the perimeter wall of the roof $\left(\mathrm{GA}_{\text {roof }}\right)$. At GR TA and SM the collection tray was installed with the same design as in $\mathrm{GA}_{\text {floor }}$.

Dust samples were collected once each week, between October 31, 2002 and October 23, 2003. The actual sampling procedure consisted of rinsing the glass trays with deionized water and scraping material adhering to the glass substrate with a rubber spatula, collecting the rinsing water in glass bottles, which were subsequently oven-dried at $40-50{ }^{\circ} \mathrm{C}$. All the supports were wet cleaned after the weekly collection with deionized water.

At first we considered to collect the samples of atmospheric dust "in dry", with small brush. However, due to the proximity to the sea of two of the collection points, the sample was naturally damp which made its gathering with brush impracticable. For that reason, for greater effectiveness, we decided to collect them from the tray, with deionized water and a rubber spatula, in spite of the fact that its deposition occurred under dry conditions.

All the trays were cleaned in situ immediately after their collection using the previously described wet method. Once dry, the samples were observed under a binocular microscope $(50 \times)$.

Four soil profiles close to each one of the selected sampling plots were described and sampled for comparative purposes (one sample per horizon). Textural and mineralogical analyses were carried out on the soil fine fraction $(<2 \mathrm{~mm})$.

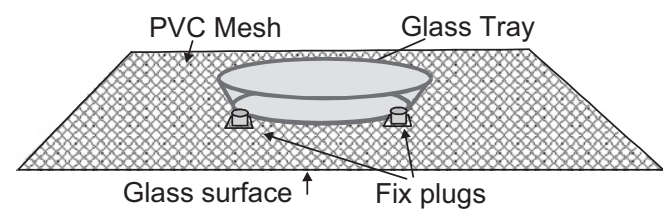

Fig. 2. Aeolian dust samplers design. It consists on glass trays (Pirex $x^{\circledR}$ ) on top of a glass surface, covered with a PVC mesh. 


\subsection{Analyses of dust and soil samples}

The main source of airborne dust on Gran Canaria is the weather condition dominated by Saharan winds (Criado and Dorta, 2003). Assuming this fact, two types of conditions were defined: haze and non-haze conditions. Another determining event is the occurrence of rainy conditions, which can represent a major depletion in atmospheric dust (Kubilay et al., 1997; Loÿe-Pilot and Martin, 1996). Dust samples were collected in rainy conditions but not analyzed due to the possibility of mixing with coarser grains (or salted grains).

Haze events were registered six times during the weekly sampling periods (Fig. 3): week 15 (1st week February 2003), week 19 (1st week March 2003), week 20 (2nd week March 2003), week 30 (3rd week May 2003), week 38 (2nd week July 2003), and week 42 (2nd week August 2003).

Non-haze conditions selected for analyses were: week 31 (4th week May 2003), week 33 (2nd week June 2003), week 34 (3rd week June 2003), week 45 (1st week September 2003) and week 48 (4th week September 2003).

Grain size analyses of airborne dust and soil silt-clay fraction were made using a Coulter LS100 laser diffractometer. Additionally, the other grain size fractions in the soil samples were dry sieved at -1 to $4 \phi$ intervals $(2-0.063 \mathrm{~mm})$. The mineralogy of the samples was further investigated by X-ray diffractometry. The range of $2 \theta$ were $2-50^{\circ}$ with a scanning step of $0.02 \%$ step and $8 \mathrm{~s} /$ step interval, since the quantity of sample was very low.

Quantitative mineralogical composition was determined by dividing the diffractogram peak areas by the following reflectivity power factors (Martín-Pozas, 1975): 0.1 for illite,

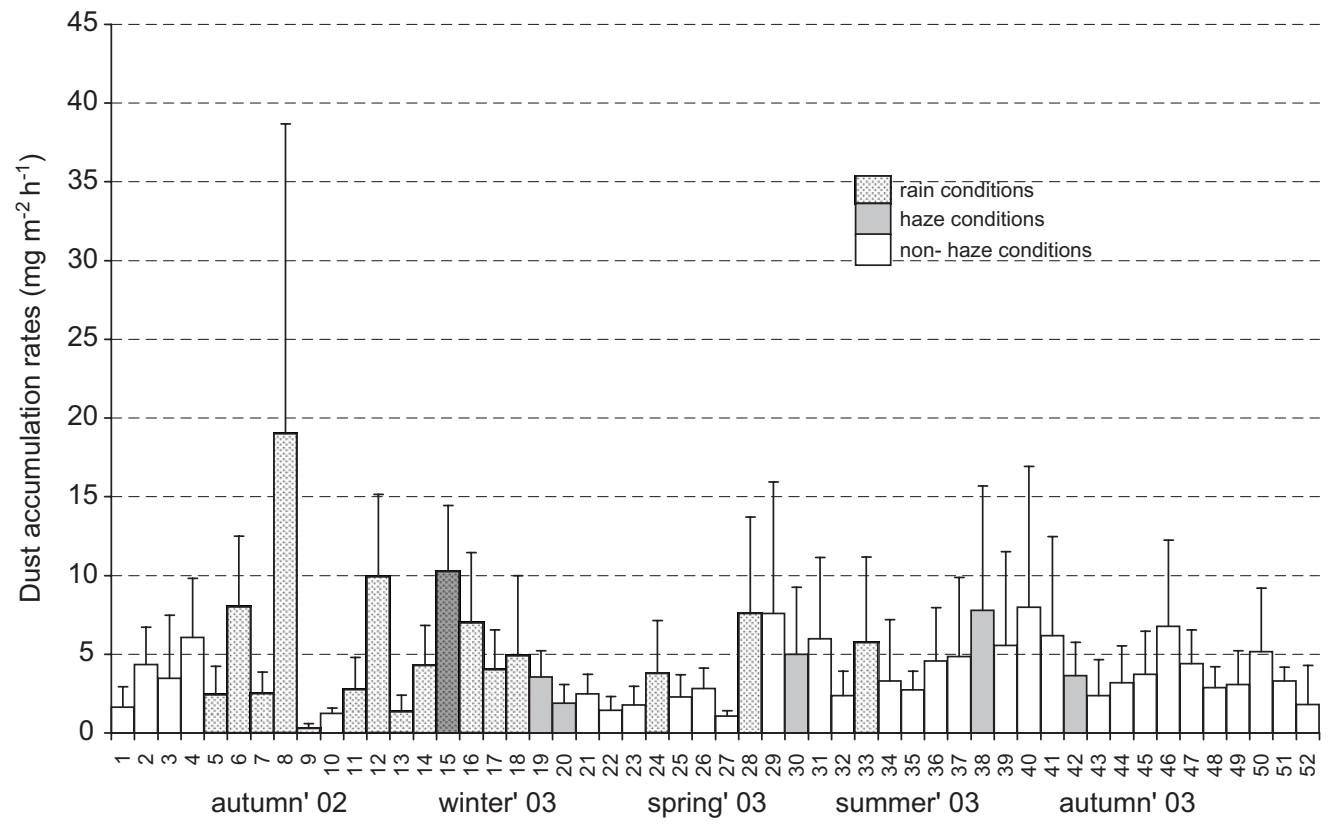

Fig. 3. Mean rates of dust accumulation in $\mathrm{mg} \mathrm{m}^{-2} \mathrm{~h}^{-1}$. Each bar represents the dust accumulations rates per week. Different situations were considered: rainy (dots square), haze (gray square) and non-haze conditions (empty square). 
palygorskite and kaolinite; 1.5 for quartz and feldspars; 1.0 for calcite, calcite-Mg, dolomite and halite; and 1.5 for magnetite. All the values where normalized to $100 \%$, assuming only the presence of crystalline phases. Scanning Electron Microscopy (SEM) and Energy Dispersive X-ray Spectroscopy (EDX) analyses were made also to corroborate the presence of the minerals detected by X-ray diffraction, and to find other minerals potentially missed or camouflaged in the diffractograms. For the SEM analysis a JEDL JSM-5400 was used. EDX was developed in the SEM equipment using an Oxford Pentrafet device with $\mathrm{Si}-\mathrm{Li}$ detector.

No disaggregating agents have been used, to preserve the possible aggregates (Matthews, 1991; Mason et al., 2003).

A bivariate statistic correlation analysis (Pearson factor) was performed using the SPSS software program.

\section{Results and discussion}

\subsection{Dust accumulation rates and climatic conditions}

The rates of dust accumulation obtained during the airborne dust monitoring (Table 2, Fig. 3) showed that rainy conditions presented the highest values $\left(5.9 \pm 5.3 \mathrm{mg} \mathrm{m}^{-2} \mathrm{~h}^{-1}\right)$, followed by haze conditions $\left(5.4 \pm 3.8 \mathrm{mg} \mathrm{m}^{-2} \mathrm{~h}^{-1}\right)$ and non-haze conditions $\left(4.3 \pm 2.1 \mathrm{mg} \mathrm{m}^{-2} \mathrm{~h}^{-1}\right)$. These values confirm the supposed tendency but not in a particularly pronounced fashion, suggesting that the rates of dust accumulation were relatively regular under these different conditions.

Haze situations were not always associated to E-SE winds (Fig. 4). The origin of the airborne particulates present under haze conditions is obviously in the Sahara area (Fig. 1), but the pattern of atmospheric circulation can give rise to wind from N-NE directions, as occurs under haze condition in March, May and July (Fig. 4). In addition, haze situations registered during the studied period were not exceptionally intense (visibility values from 600 to $900 \mathrm{~m}$ ), compared to, for example, the exceptional haze event from January 5 to 10 , 1999, where visibility values were reduced to $500 \mathrm{~m}$ (Criado and Dorta, 2003). Annual percentage of days with haze conditions during the period studied (2002-2003) was only $13 \%$, a lower value than the average of $25 \%$ defined by Dorta (1999). Therefore, our values could underestimate the potential accumulation rate.

Table 2

Dust accumulation rates (in $\mathrm{mg} \mathrm{m}^{-2} \mathrm{~h}^{-1}$ ) for Gran Canaria plots, on haze, non-haze and rain regime

\begin{tabular}{|c|c|c|c|c|c|c|c|c|}
\hline \multirow[t]{2}{*}{ Plot } & \multicolumn{2}{|c|}{ Haze conditions accum. } & \multicolumn{2}{|c|}{ Non-haze conditions accum. } & \multicolumn{2}{|c|}{ Rain conditions } & \multicolumn{2}{|c|}{ Total dust accumulation } \\
\hline & Rate & $\mathrm{SD}$ & Rate & $\mathrm{SD}$ & Rate & $\mathrm{SD}$ & Mean & $\mathrm{SD}$ \\
\hline $\mathrm{GA}_{\text {floor }}$ & 9.6 & 7.1 & 9.9 & 3.7 & 6.7 & 8.5 & 9.1 & 7.6 \\
\hline $\mathrm{GA}_{\text {roof }}$ & 6.6 & 3.5 & 5.2 & 1.7 & 12.0 & 10.4 & 5.0 & 2.9 \\
\hline GR & 5.7 & 3.8 & 2.2 & 0.9 & 5.2 & 2.9 & 4.1 & 5.3 \\
\hline TA & 2.4 & 1.7 & 3.1 & 3.7 & 3.1 & 2.9 & 2.1 & 1.9 \\
\hline $\mathrm{SM}$ & 2.5 & 3.0 & 1.3 & 0.8 & 2.4 & 1.9 & 2.0 & 1.9 \\
\hline Mean & 5.4 & 3.8 & 4.3 & 2.1 & 5.9 & 5.3 & 4.5 & 3.9 \\
\hline
\end{tabular}




\section{HAZE CONDITIONS}
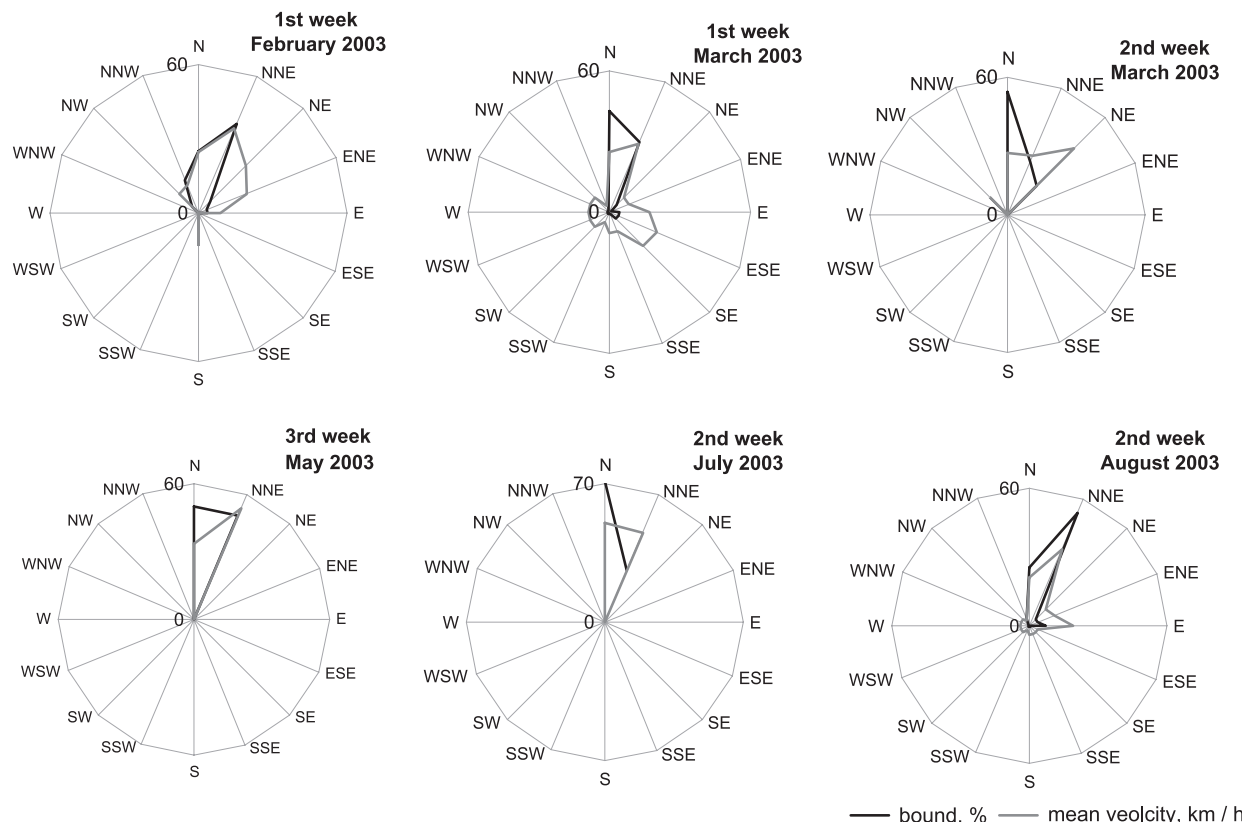

NON-HAZE CONDITIONS
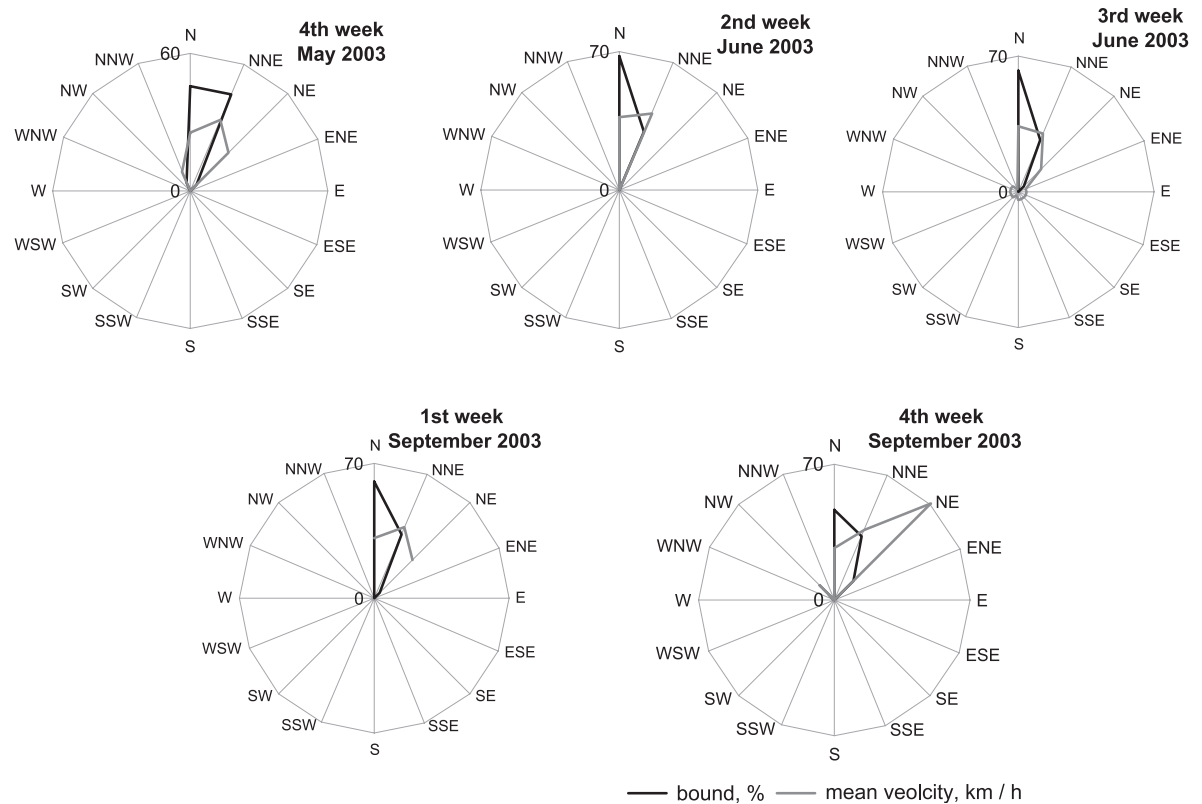

Fig. 4. Wind bounds (in percentage) and velocities (in $\mathrm{km} \mathrm{s}^{-1}$ ) during the sampling period (October 2002-October 2003) differentiating haze and non-haze conditions. 


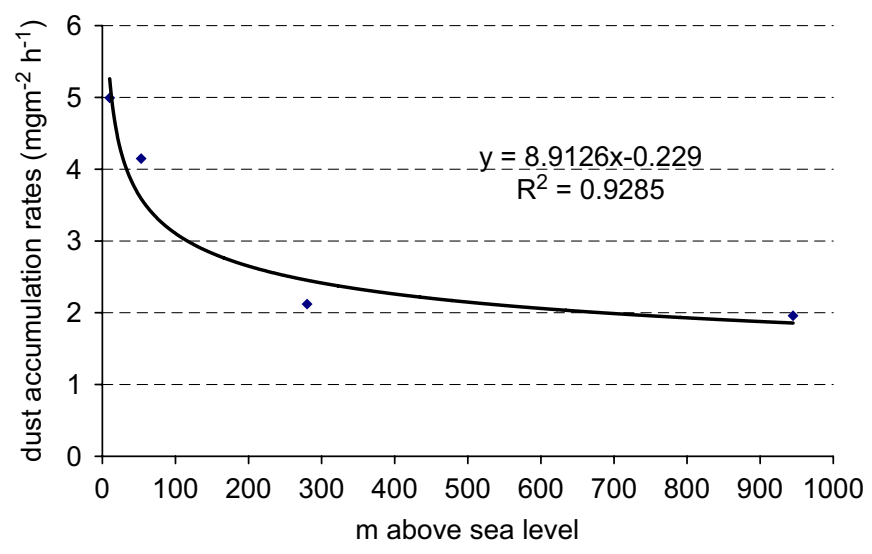

Fig. 5. Mean values of dust accumulation rates (in weigh \%) respecting to altitude at the studied plots. Potential fitting was accurate.

Mean values of dust accumulation rates decrease with increasing altitude (from $9.1 \mathrm{mg} \mathrm{m}^{-2} \mathrm{~h}^{-1}$ at $10 \mathrm{~m}$ a.s.1. to $2.0 \mathrm{mg} \mathrm{m}^{-2} \mathrm{~h}^{-1}$ at $945 \mathrm{~m}$ a.s.1., Table 2 and Fig. 5), equivalent to annual accumulation rates of 79 and $17 \mathrm{~g} \mathrm{~m}^{-2} \mathrm{yr}^{-1}$, respectively, and reflecting a gravitational settling effect. These values reflect the vertical distribution of dust in the lower atmosphere (Offer and Goossens, 2004). The negative B exponent of the power function (Nickling, 1978; Fig. 5) means that the amounts of dust in the atmosphere decreased with height.

The dust accumulation rates were in the general range of those measured in the S-SE of Spain (23 $\mathrm{g} \mathrm{m}^{-2} \mathrm{yr}^{-1}$; Díaz-Hernández and Miranda, 1997) and somewhat lower than those for the African coast of Niger $\left(94 \mathrm{~g} \mathrm{~m}^{-2} \mathrm{yr}^{-1}\right.$; Herrmann et al., 1996). Dust deposition rates calculated for the geographic position of the Canary Islands were, for instance, in the low range of those found in this work $\left(16 \mathrm{~g} \mathrm{~m}^{-2} \mathrm{yr}^{-1}\right.$; Prospero, 1996). The estimation of dust accumulated in two soil profiles from Lanzarote for the last $260 \mathrm{yr}$ was $5-6 \mathrm{~kg} \mathrm{~m}^{-2}$ (Herrmann et al., 1996), which corresponds to an annual accumulation rate of $20 \mathrm{~g} \mathrm{~m}^{-2} \mathrm{yr}^{-1}$ for that island, and is in the same range of accumulation rates obtained in Gran Canaria.

Statistical analysis showed that the accumulation rate was positively correlated with maximum wind values $\left(R^{2}: 0.585-0.701, N=23-40\right.$, significance level of 0.05 ; excepting for TA samples) and with rainy conditions $\left(R^{2}: 0.410-0.779, N=23-40\right.$, significance level of 0.05; excepting for $\mathrm{GA}_{\text {wall }}$ and TA samples). However, accumulation rates were not always correlated between all locations. For instance, $\mathrm{GA}_{\text {floor }}$ was not correlated with TA; neither GM with GR or SM; or GR with TA. This could reflect the variability of local wind conditions relative to the accumulation rates on NE of Gran Canaria.

\subsection{Textural analyses of aeolian dust samples}

Dust samples components were mostly of coarse silt grain size $(46 \pm 12 \%)$ with low clay percentage $(8 \pm 9 \%$; Table 3$)$. Grain size distribution curves were polymodal, centered around $1.5-2 \mu \mathrm{m}$ (clays), 6-8 $\mu \mathrm{m}$ (very fine-fine silts), 22-35 $\mu \mathrm{m}$ (coarse silt) and $62-130 \mu \mathrm{m}$ (very fine sands; Fig. 6). 
Table 3

Texture analyses of Gran Canaria dust samples. Haze and non-haze situations were distinguished

\begin{tabular}{|c|c|c|c|c|c|c|}
\hline \multirow[t]{2}{*}{ Grain size $(\%)$} & \multicolumn{2}{|l|}{ Haze } & \multicolumn{2}{|c|}{ Non-haze } & \multicolumn{2}{|c|}{ Total dust } \\
\hline & Mean & SD & Mean & SD & Mean & SD \\
\hline Clay $(<2 \mu \mathrm{m})$ & 8 & 6 & 7 & 13 & 8 & 9 \\
\hline v.f.-f. silt $(2-8 \mu \mathrm{m})$ & 17 & 11 & 13 & 7 & 16 & 10 \\
\hline m. $\operatorname{silt}(8-16 \mu \mathrm{m})$ & 16 & 6 & 18 & 14 & 16 & 9 \\
\hline c.-v.c. silt $(16-62 \mu \mathrm{m})$ & 45 & 11 & 49 & 14 & 46 & 12 \\
\hline v.f. sand $(62-125 \mu \mathrm{m})$ & 19 & 16 & 15 & 15 & 17 & 15 \\
\hline
\end{tabular}

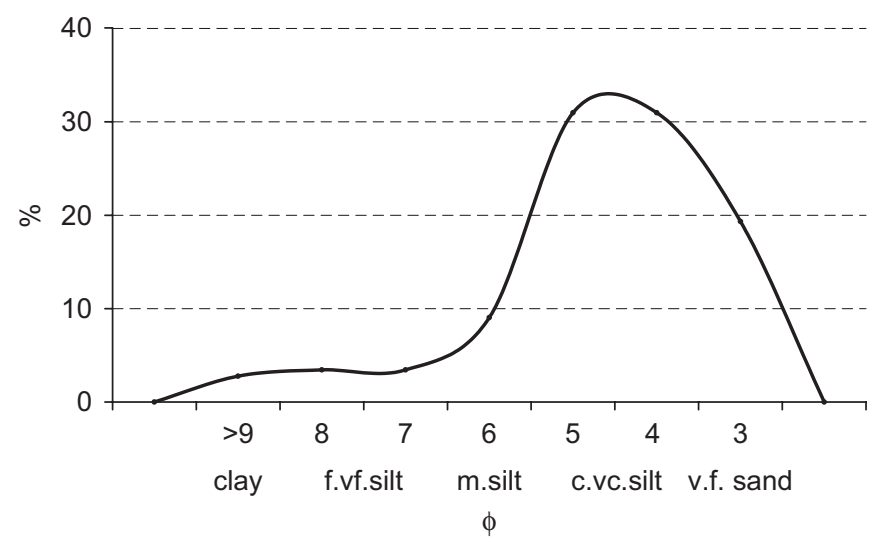

Fig. 6. Polymodal textures form the aeolian dust samples of Gran Canaria.

Loess generally shows a bimodal grain-size (Donghuai et al., 2004). That was the case in Chinese loess, with two maxima at 2-10 and 20-50 $\mu \mathrm{m}$, which led Donghuai et al. (2004) to argue that more than one sedimentary transportation process was responsible for this grain-size distribution.

The very fine and fine silts, as well as the coarse silt modes in Gran Canaria could represent the bimodal trend of loess described before. However, the very fine sand population could be transported by saltation, if the results of Pye (1987) and Bauer et al. (2004) are taken into account. These sands should come from a proximal local source, transported by the wind. The clay fraction could also originate from local soils, where clays minerals are present (Table 1) or from airborne Saharan dust.

Haze samples show a fairly marked tendency to increased amounts of the very fine-fine silt and the coarse silt fraction, and reduced mounts in the very fine sand fraction (Table 3 ). This corresponds to a predominance of fine suspension and accumulation during haze conditions. In general, the granulometry curve showed a very strong positive skewness $(0.96 \pm 0.6)$, more pronounced for haze samples $(1.0 \pm 0.5)$, probably reflecting a predominance of long distance transport. Airborne dust from haze conditions collected in the island of Tenerife presented very strong skewness as well (Criado and Dorta, 2003), which were also considered evidence of suspension transport (Nickling, 1983). Mesokurtic curves are predominant for both haze and non-haze condition samples (1.0 \pm 1.4$)$. 
Silt fractions were positively correlated with the accumulation rates obtained $\left(R^{2}=0.292, N=55\right)$, but negatively correlated with sand fraction $\left(R^{2}=-0.283\right.$, $N=55)$, although the significance level in all cases was lower than $0.05 \%$. Therefore, the higher accumulation rates corresponded with the higher silt content and lower sand content, in agreement with suspension transport during haze conditions.

The dominant colors of dust samples were visually estimated by means of Munsell Color Charts as 10YR 6-5/3-4 (brown, brown-yellow). The lightest colors corresponded to haze conditions and samples obtained from the GA plot. Binocular inspection detected carbonaceous particles (black spherulites and soot), with a visually estimated percentage of $10-20 \%$. This value was slightly higher than in Lanzarote (3\%, Herrmann et al., 1996) which is smaller and less populated island than Gran Canaria. Other minor components present in the samples were vegetal filaments.

\subsection{Mineralogical analyses of dust samples}

The mean content and the standard deviation of the main minerals detected by XRD in the airborne dust from the island of Gran Canaria were (Table 4; Fig. 7): quartz $(42 \pm 22 \%)$, Mg-calcite $(19 \pm 13 \%)$, calcite $(11 \pm 8 \%)$, feldspars $(11 \pm 8 \%)$, dolomite $(8 \pm 6 \%)$, magnetite $(7 \pm 8 \%)$, aragonite $(2 \pm 5 \%)$, halite $(1 \pm 2 \%)$, and very low quantities of illite $(0.1 \pm 0.1 \%)$, kaolinite-chlorite and palygorskite $(<0.1 \pm 0.1 \%)$. The mineralogical reference for Saharan dust compositions reveal high quartz abundances with low quantities of clays, feldspars, calcite and halite (Goudie and Middleton, 2001; Kiefert and Mc Tainsh, 1996). This too was registered in Gran Canaria samples, where quartz is also dominant, in combination with carbonate minerals. Quartz has a clear allochthonous origin (Fig. 8), since the volcanic rocks in this archipelago rarely contain this primary mineral, although it can be potentially recycled once here. Since the mean quartz percentage in haze condition samples was around $10 \%$ greater than in non-haze condition samples, this supports an external source. However the high overall quartz content already mentioned above, suggests that originally allochthonous quartz becomes subsequently a

Table 4

Mineral composition detected by XRD in the airborne dust samples, differentiating haze and non-haze conditions, and mean mineral composition of the $A$ horizon from the study plots

\begin{tabular}{|c|c|c|c|c|c|c|c|c|}
\hline & \multicolumn{2}{|l|}{ Haze } & \multicolumn{2}{|c|}{ Non-haze } & \multicolumn{2}{|c|}{ Total dust } & \multicolumn{2}{|c|}{$A$ horizon } \\
\hline & Mean & $\mathrm{SD}$ & Mean & $\mathrm{SD}$ & Mean & $\mathrm{SD}$ & Mean & $\mathrm{SD}$ \\
\hline Palygorskite & 0.02 & 0.06 & 0.02 & 0.07 & 0.02 & 0.07 & 1.57 & 2.25 \\
\hline Illite & 0.1 & 0.1 & 0.1 & 0.1 & 0.1 & 0.1 & 0.7 & 1.5 \\
\hline Kaolinite-chlorite & 0.1 & 0.1 & 0.1 & 0.1 & 0.1 & 0.1 & 0.2 & 0.3 \\
\hline Aragonite & 3 & 6 & 1 & 4 & 2 & 5 & 0.3 & 0.6 \\
\hline Quartz & 46 & 19 & 36 & 24 & 42 & 22 & 38 & 36 \\
\hline Feldespars & 12 & 11 & 11 & 5 & 11 & 8 & 6 & 8 \\
\hline Calcite & 10 & 7 & 12 & 9 & 11 & 8 & 22 & 34 \\
\hline Mg calcite & 15 & 11 & 22 & 15 & 19 & 13 & 5 & 6 \\
\hline Dolomite & 7 & 5 & 9 & 5 & 8 & 6 & 6 & 13 \\
\hline Halite & 1.4 & 2.2 & 0.7 & 0.8 & 1.1 & 1.8 & 0.2 & 0.3 \\
\hline Magnetite & 6 & 6 & 8 & 10 & 7 & 8 & 17 & 28 \\
\hline
\end{tabular}




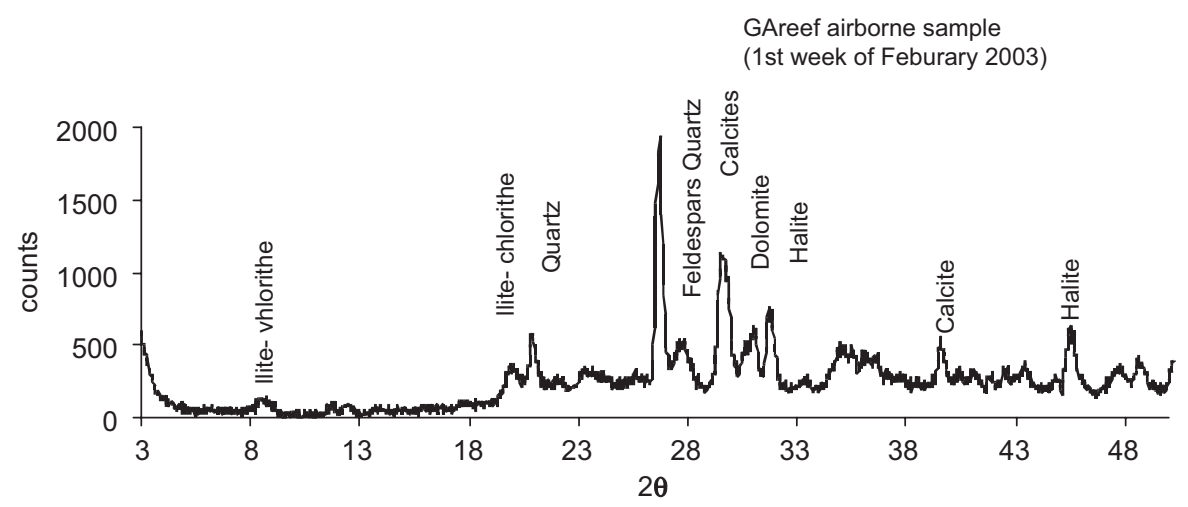

Fig. 7. X-ray diffractogram of aeolian dust collected in GA plot from a haze situation.
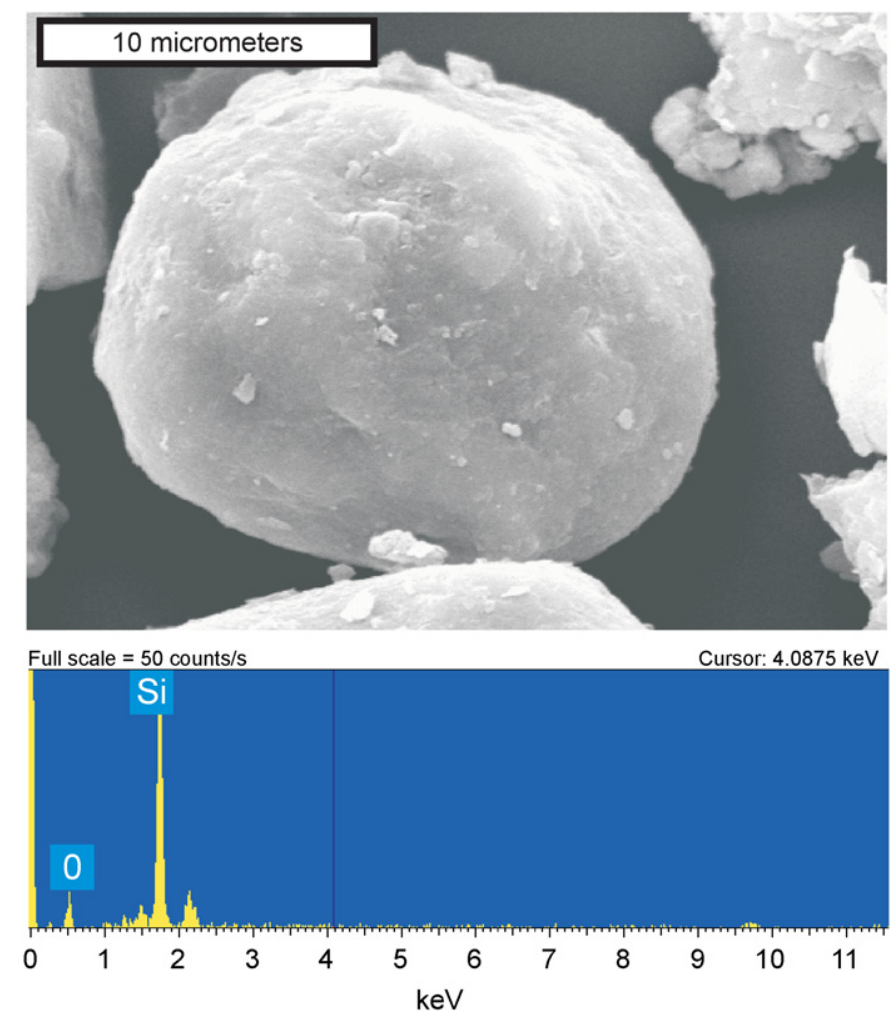

Fig. 8. SEM micrograph and EDS spectrum of a quartz mineral from the airborne dust collected in GA.

recycled input, generating a high quartz background in insular airborne particulates (Table 4). The quartz concentration in the airborne dust for non-haze conditions was very high as well.

In spite of feldspars and magnetite being common primary minerals of the various volcanic substrates of Gran Canaria, these minerals can also be allochthonous, transported 
from the neighboring African continent. Similarity to quartz, these minerals could be recycled later in the airborne dust of the island. The average concentration of feldspars in haze samples was $1 \%$ higher than in non-haze samples, while that for magnetite mean was $2 \%$ lower for haze samples than form non-haze samples (Table 4). The studied carbonate particles can originally proceed from marine sedimentary deposits (aragonite, calcite, Mgcalcite and dolomite) and from soils (calcite) within the island, or derive from Saharan rocks and soils, and be subsequently recycled. The aragonite average concentration was somewhat higher $(1 \%)$ in haze samples, but calcite, Mg-calcite and dolomite average concentrations were noticeably lower $(2 \%, 7 \%$, and $2 \%$ respectively, Table 4$)$.

The clay minerals of the airborne dust can derive from insular soils as well as from the Saharan region. Haze and non-haze conditions showed uniformly low concentrations and similar percentages for clay minerals (Table 4).

The encountered halite crystals, of marine origin (Fig. 9), were present in low concentrations in the studied samples and showed no variations betweens haze and nonhaze conditions (Table 4). An altitudinal decrease in halite concentrations was observed as should be expected with increasing distance from the coast. By contrast, an altitudinal increase in kaolinite-chlorite was detected, but the rest of the airborne dust minerals did not registered noticeable variations with altitude (Fig. 10).
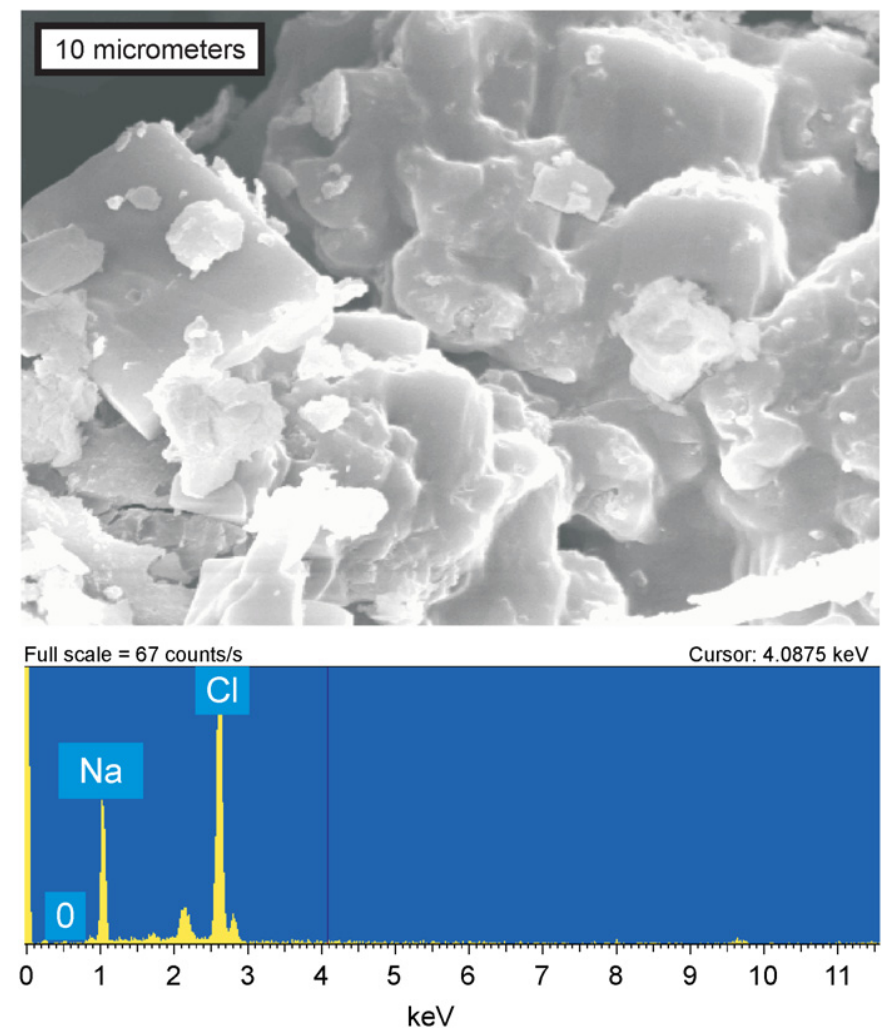

Fig. 9. SEM micrograph and EDS spectrum of a halite mineral from the airborne dust collected in GA. 


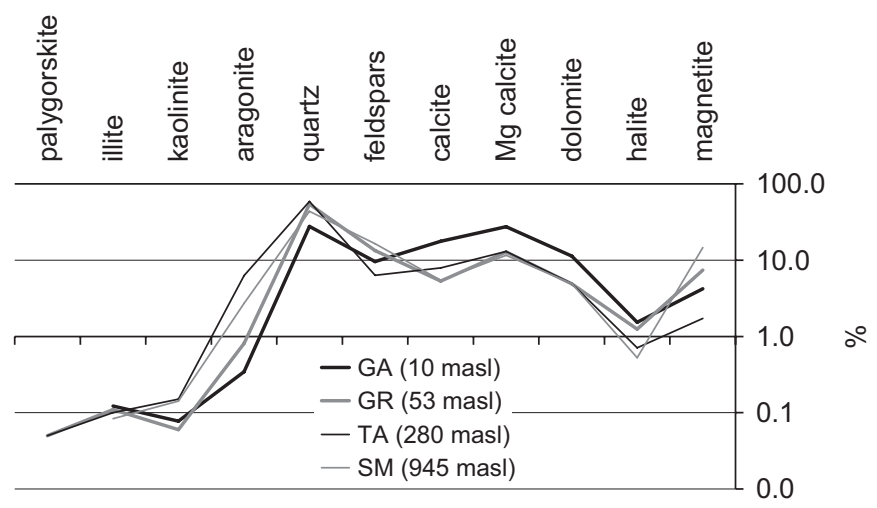

Fig. 10. Mineralogical composition of the airborne dust collected in the study, respecting to altitude.

Gran Canaria dust samples showed a positive statistic correlation between quartz, illite, kaolinite and feldspars concentrations, probably due to a common Saharan source. A similar positive correlation exists between halite and the previously mentioned minerals, but in this case, halite is primarily of marine origin.

Although the volcanic substrate of the sampling plots is often composed of olivine (forsterite), clinopyroxenes (augite and diopside), amphibole (hornblende), feldespatoids (nepheline and hauyne), and zeolites (chabasite and phillipsite), among others, the studied aeolian dust samples either did not contain these minerals at all, or in some cases only in minimal amounts. This could be due to the comparatively large rock grains sizes (phenocryst and microcryst up to $0.06 \mathrm{~mm}$ ) and low fragmentation, or the transformation through weathering in other minerals. It could also be due to the prominence of external airborne dust that reduces the proportion of these minerals below the detection limit of the analytical techniques employed.

\subsection{Airborne dust input in soils on Gran Canaria}

\subsubsection{Dust accumulation (in soils on Gran Canaria)}

Assuming that $50 \%$ of accumulated dust on soil is finally stabilized, and that the average of the apparent density of dust constituents, as reported from available literature, vary from 1.0 (Cattle et al., 2002) to $1.35 \mathrm{~g} \mathrm{~cm}^{-3}$ (Simonson, 1995), the potential increase in soil thickness, due to accumulated dust on the island of Gran Canaria could range from 0.14-36.48 $\mathrm{m}$, depending on the age of the soil. The obtained values are disproportionately high for the oldest soils (sampling plots GR and SM, Table 5(a)) with respect to their real thickness (1.5-2.0 m; Table 5(e)).

Taking these results into account, the stabilization of airborne dust in Gran Canaria has been overestimated in relation to previous figures from literature. Significantly less than the estimated $50 \%$ of accumulated dust seems to be finally stabilized according to our study. This could be due to leaching and erosion of soil profiles, which eliminated most of the accumulated dust. In fact, the estimated mean actual erosion rates for these areas should be taken into account in our calculations $\left(7.5 \mathrm{~kg} \mathrm{~m}^{-2} \mathrm{yr}^{-1}\right.$ for GA and $2.5 \mathrm{~kg} \mathrm{~m}^{-2} \mathrm{yr}^{-1}$ for GR, TA and SM; Cendrero et al., 1990). 


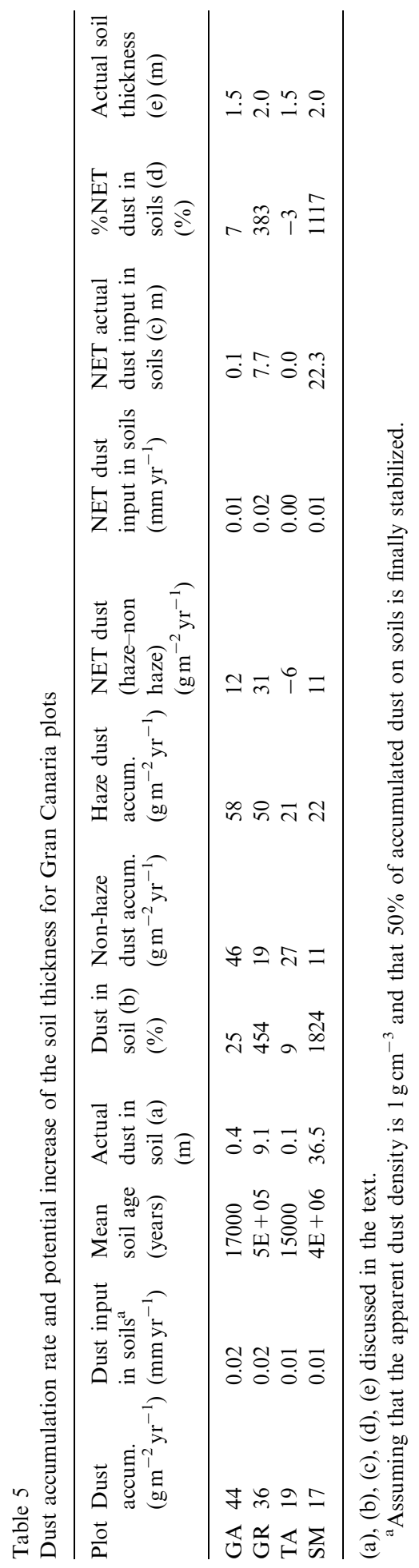


Otherwise, it is necessary to quantify the effect of recycled airborne particles to determine the stabilized aeolian dust in soils. This recycling effect is caused by local remobilization of material before final deposition. In oceanic island environments with desert influence (as in our study case), this recycling effect can be more easily quantifiable than in continental areas, because all aeolian dust imported from external sources to the island is clearly recognizable as a new and allochthonous input to the island soils. Thus, there is a difference between non-haze conditions (assuming only local recycled dust input) and haze conditions (assuming both external and local recycled dust input) with the result corresponding to an approximated net input of dust:

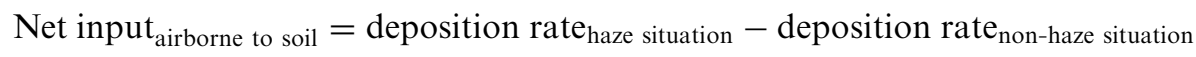

Considering this net input of aeolian dust values instead of total accumulation rates, a decrease in the final proportion of dust accumulated was obtained in our study, which is still high for the oldest soils (plots GR and SM; Table 5(c)).

In summary, it could be deduced that: aeolian dust stabilization has been overestimated in the case of the island of Gran Canaria; the determinant factors in soil accumulation rates was leaching and soil erosion rates; and that these variations could specially affect older soils.

Haze phenomena should have been occurring in the Canary Archipelago ever since the Saharan region acquired its desert character. According to the studies of Giraudi (2005), this occurs at least in the last 80,000 yr. The lowest frequency of haze conditions would correspond to wet-glacial phases (less than $\sim 20 \%$ for the interval $14,800-55,000 \mathrm{yr}$; De Menocal et al., 2000). All throughout this period, recurring inputs of quartz on soils in Gran Canaria take place, resulting in a large reservoir of this mineral being formed that allows the possibility of subsequent recycling in airborne dust.

With airborne quartz particles in Gran Canaria having an external origin, and this mineral also being stable in the weathering conditions of the studied soils, it can be regarded as a good index mineral for dust accumulations rates. The net input (1) of quartz in $A$ horizon was $23 \pm 13 \%$ for plot GA; $-7 \pm 6 \%$ for plot GR; $-8 \pm 7 \%$ for plot TA; and $10 \pm 5 \%$ for plot SM (Table 6). Thus, the recycling effect was quite pronounced (low net input values) in plots GA and TA, and even greater than external input in plots GR and SM (negative net input values). Negative values in plots GR and SM, which correspond to

Table 6

Quartz amounts in $A$ horizon and in the aeolian dust samples of the study plots, considering the net input concept (formula 1)

\begin{tabular}{|c|c|c|c|c|c|c|c|c|}
\hline & \multicolumn{8}{|c|}{ Quartz percentage } \\
\hline & GA & $\mathrm{SD} \pm$ & GR & $\mathrm{SD} \pm$ & $\mathrm{TF}$ & $\mathrm{SD} \pm$ & $\mathrm{SM}$ & $\mathrm{SD} \pm$ \\
\hline Haze & 36 & 20 & 52 & 18 & 56 & 12 & 45 & 22 \\
\hline Non-haze & 13 & 7 & 59 & 12 & 64 & 5 & 35 & 17 \\
\hline Net input & 23 & 13 & -7 & 6 & -8 & 7 & 10 & 5 \\
\hline$A$ horizon & 11 & - & 77 & - & 39 & - & 61 & - \\
\hline Dust $\% / A$ horizon $^{\mathrm{a}}$ & 207 & - & - & - & - & - & 609 & - \\
\hline
\end{tabular}

\footnotetext{
${ }^{\text {a }}$ Percentage of dust in $A$ horizon, considering quartz as a reference mineral.
} 
the oldest and more stable soils in the current study, can be interpreted as the progressive accumulation through time of this stable mineral. This explains its increased proportion in soils relative to airborne dust.

The proportions of quartz in the $A$ horizon relative to the proportion in aeolian dust, considering only the net input (1), was $11 / 23 \%$ for plot GA, $77 /-7 \%$ for plot GR, $39 /-8 \%$ for plot TA and $61 / 10 \%$ for plot SM (Table 6). This means, that the $48 \%$ of the $A$ horizon in plot GA would have been contributed by airborne dust accumulation. This result is higher than previously estimated for plot GA (25\% versus 7\%; Table 5(b) and (d)), but this may be possibly due to a relative quartz enrichment in soils with respect to the rest of airborne components. In the SM plot case, aeolian quartz proportion in $A$ horizon was very significant, and its justification could be the same as in plot GA. The negative denominator for the proportion of quartz in plots GR and TA are within standard error range and were therefore not considered (Table 6).

\subsubsection{Grain size and mineral composition influence of aeolian dust (in soils on Gran Canaria)}

Grain size distribution in the aeolian dust on Gran Canaria is polymodal. The mode of particle sizes in the coarse silt range found in soil horizons of the island of Gran Canaria coincides with that characteristic of airborne dust (Cattle et al., 2002; Kleber, 2000; Walker et al., 1988; Fig. 11). Also, the fine fraction frequency increased with depth: $20-30 \%$ more in lower horizons (Fig. 11). This can be interpreted as a translocation of fine fraction to
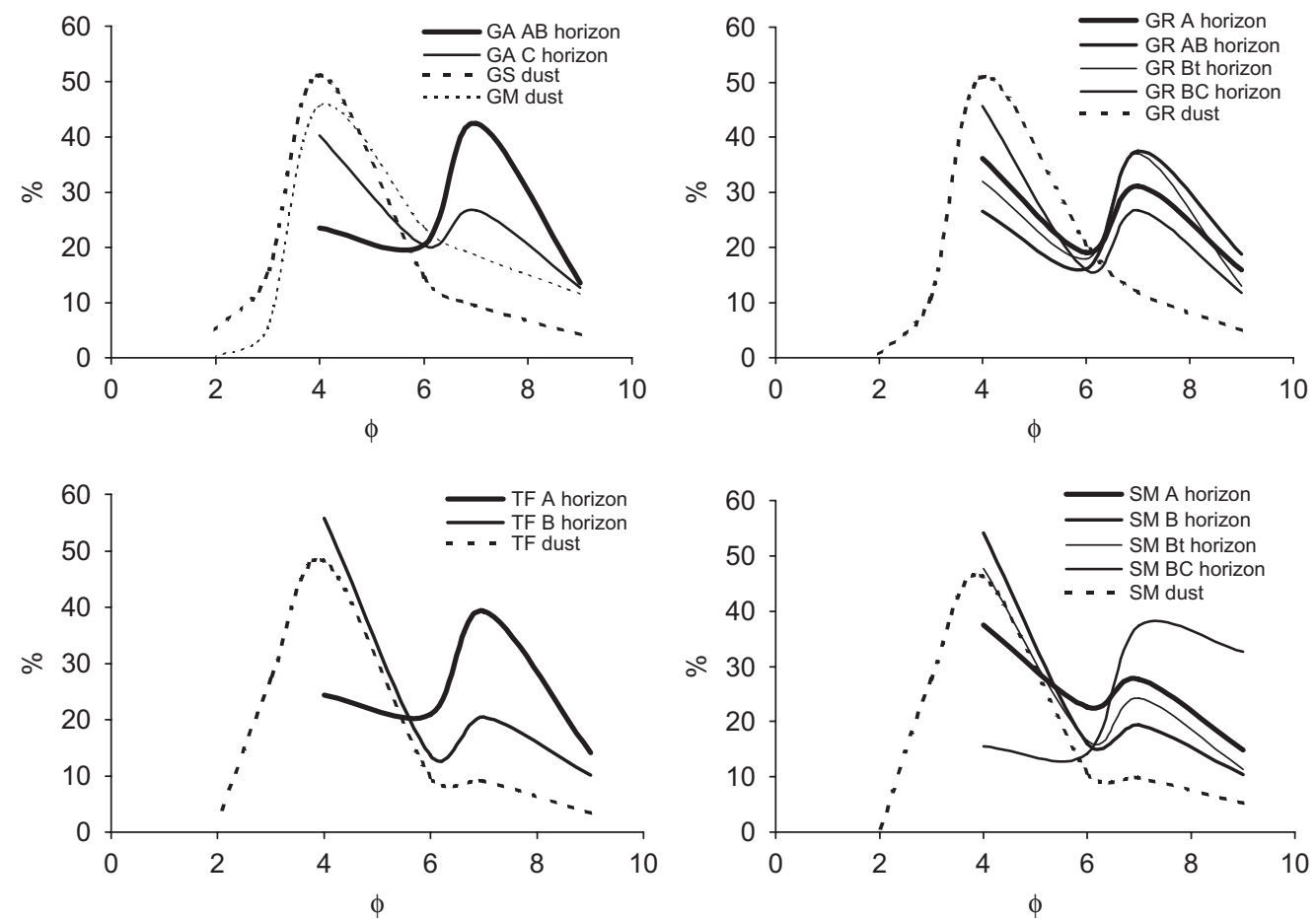

Fig. 11. Particles size distribution of the airborne dust and the soil profile samples, collected at the different plots. 
deeper horizons (Herrmann et al., 1996; Kleber, 2000). Finally, another of the modal grain maxima in analyzed soil from Gran Canaria fell in very fine silt-clay range, which is characteristic of weathering products.

The typical secondary minerals in the studied soils were palygorskite and halloysite (Sánchez, 1975, Table 1). The soil samples showed higher concentrations in palygorskite (from $0.02 \%$ to $1.6 \%$ ), illite (from $0.1 \%$ to $0.7 \%$ ), calcite (from $11 \%$ to $22 \%$ ) and magnetite (from $7 \%$ to $17 \%$ ) than dust samples. These higher concentrations are possibly secondary in origin, or residual products related to edaphic activity. By contrast, aragonite and $\mathrm{Mg}$-calcite (both derived from marine sources), feldspars (generally more susceptible to alteration) and halite (easily soluble mineral of marine origin) were present in lower concentration in the analyzed soils relative to the airborne dust collected on the plots (Table 4).

Euhedral dolomite was observed in scanning electron micrographs (SEM-EDX) of the GA-site soil (Fig. 12). Soils at this location developed over an aeolian sand field supplied from a nearby back-beach area. Dolomite of marine origin, subsequently transported into a high-energy beach environment is expected to suffer noticeable shape erosion. This has not been observed, however, in dolomite crystals found in soils from the GA plot. Therefore this mineral is likely to be authigenic. Other examples of edaphic dolomites,
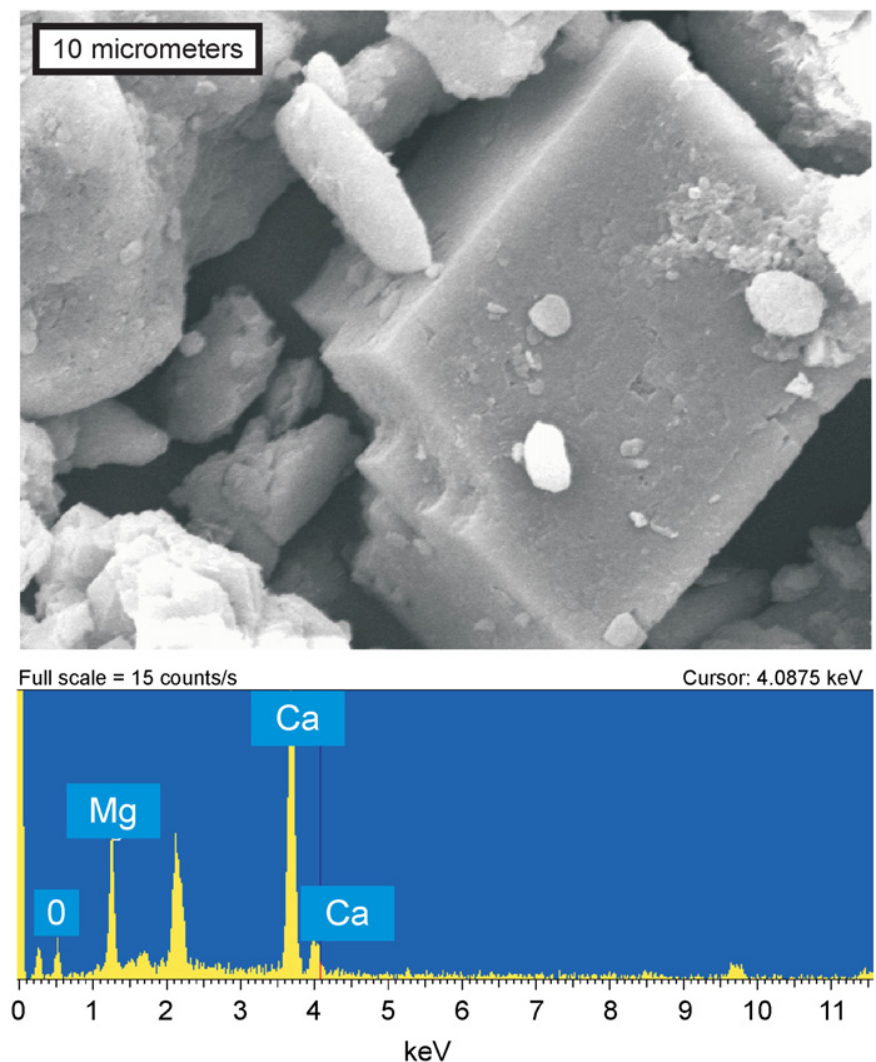

Fig. 12. SEM micrograph and EDS spectrum of a well-shaped dolomite crystal from the silt-clay sample fraction collected at the $A$ horizon of GA soil. 
confirmed by isotopic characterization, have been documented in Hawaiian soils (Capo et al., 2000). In fact, aeolian samples from GA plot also contain prismatic dolomite displaying smoothly rounded edges (Fig. 13), which could be due to aeolian abrasion prior to reincorporation in the soil profile.

Comparing the percentage of dolomite in soils from the different sampling plots (Table 7, Fig. 14), there was a marked difference between site GA $(33.5 \%)$ and the others sites $(<4.8 \%)$. Furthermore, the amount of dolomite in the aeolian sample of the GA plot
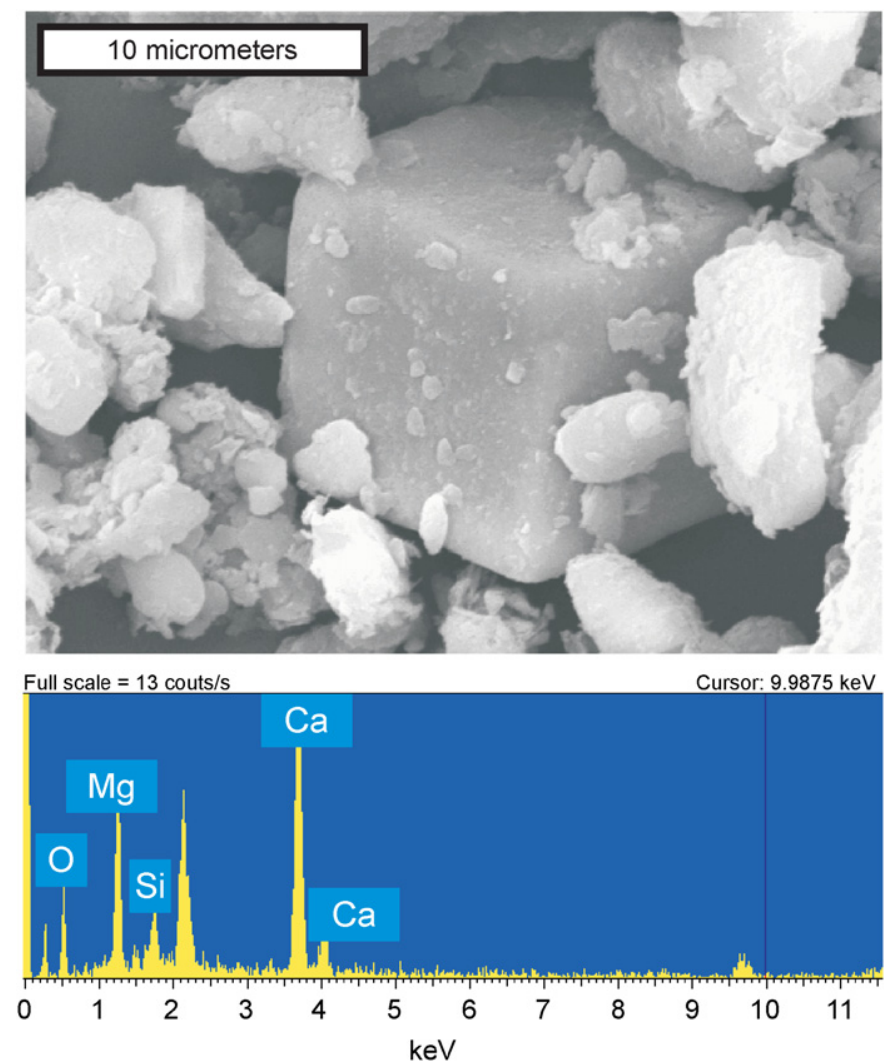

Fig. 13. SEM micrograph and EDS spectrum of a rounded dolomite crystal from the Aeolian dust sample collected at the GA plot.

Table 7

Dolomite amounts in soils and airborne dust at different plots

\begin{tabular}{|c|c|c|c|c|c|c|c|}
\hline \multirow{2}{*}{$\begin{array}{l}\text { Dolomite } \\
\text { Plots }\end{array}$} & \multirow[t]{2}{*}{ Soil (\%) } & \multicolumn{2}{|c|}{ Airborne dust } & \multicolumn{2}{|c|}{ Haze } & \multicolumn{2}{|c|}{ Non-haze } \\
\hline & & $(\%)$ & $( \pm)$ & $(\%)$ & $( \pm)$ & $(\%)$ & $( \pm)$ \\
\hline GA & 34 & 11 & 6 & 10 & 6 & 14 & 5 \\
\hline GR & 1 & 5 & 4 & 5 & 5 & 4 & 2 \\
\hline TA & 5 & 5 & 4 & 4 & 4 & 6 & 5 \\
\hline SM & 0 & 5 & 2 & 5 & 2 & 6 & 1 \\
\hline
\end{tabular}



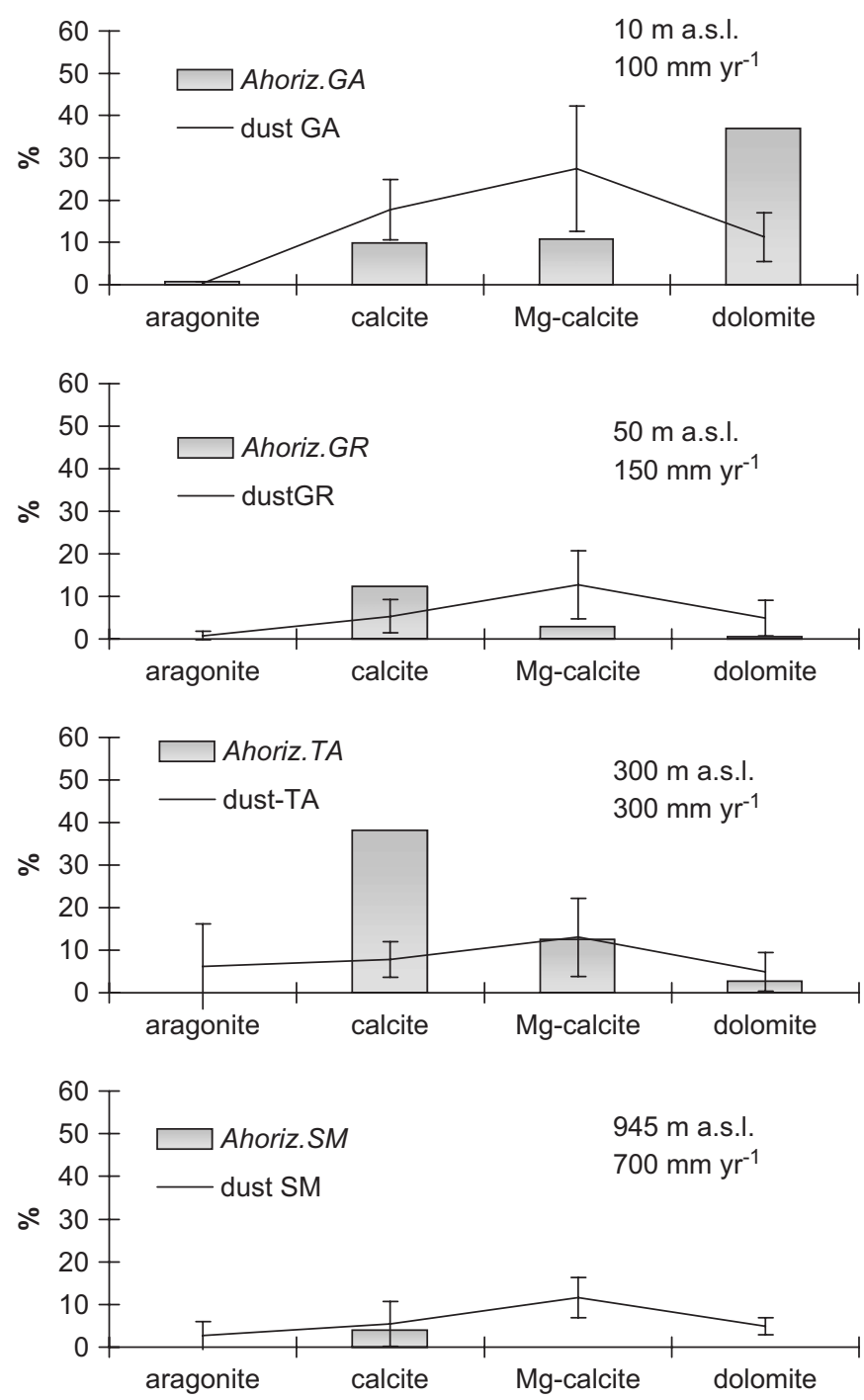

Fig. 14. Carbonate minerals content in the soils and Aeolian dust samples with different plots conditions (altitude and pluviometry).

sample is double that of all other aeolian samples $(11.3 \%$ versus $<5.4 \%)$. In general, the percentage of dolomite for samples collected under haze conditions was lower than those collected under non-haze conditions (Table 7). Therefore, dolomite crystals are derived mainly from a local source.

The amount of carbonate minerals in the $A$ horizon was noticeable at sampling plots located at altitudes between 0 and $300 \mathrm{~m}$ (sites GA, GR and TA), but undetectable in the highest altitude plot (site SM, located at $945 \mathrm{~m}$; Fig. 14). Otherwise, the input of carbonate minerals in airborne dust was relatively constant at every sampling plot. Thus, the absence of carbonates in SM site should be attributed mainly to higher rainfall $\left(700 \mathrm{~mm} \mathrm{yr}^{-1}\right)$. This 
average rainfall is well above the arid-semiarid conditions necessary for the formation and preservation of carbonate in soils $\left(500 \mathrm{~mm} \mathrm{yr}^{-1}\right)$. In fact, the SM area is considered as humid environment by Sánchez et al., (1995), and therefore not adequate for carbonate precipitation because soil humidity tends to remove $\mathrm{Ca}$ from the weathering profile by leaching (Egli and Fitze, 2001; Knauth et al., 2003).

\section{Conclusions}

Airborne dust accumulation rates in the island of Gran Canaria had values of $5.4 \pm 3.8 \mathrm{mg} \mathrm{m}^{-2} \mathrm{~h}^{-1}$, in the presence of wind blown Saharan dust (haze conditions), $20 \%$ higher than under non-haze conditions $\left(4.3 \pm 2.1 \mathrm{mg} \mathrm{m}^{-2} \mathrm{~h}^{-1}\right)$. However, the haze conditions were not exceptionally intense in the studied period. In addition, mean values of dust accumulation rates were found to decrease with increasing altitude, from 79 to $17 \mathrm{~g} \mathrm{~m}^{-2} \mathrm{yr}^{-1}$, reflecting the gravitational settling pattern.

Texturally, components of collected dust samples were mostly in the coarse silt grain fraction $(46 \pm 12 \%)$ with low clay size percentages $(8 \pm 9 \%)$. Grain size distribution curves were found to be polymodal with maxima corresponding to very fine-fine silt, coarse silt, and very fine sands modes. There was an increase in the very fine-fine and coarse silt fraction, and a decrease of the coarse silt fraction for haze samples, in agreement with conditions of suspension transport prior to accumulation.

The observed airborne dust mineralogy was: quartz $(42 \pm 22 \%)$, carbonates $(40 \pm 32 \%)$, feldspars $(11 \pm 8 \%)$, magnetite $(7 \pm 8 \%)$, halite $(1 \pm 2 \%)$, with very low amounts of illite $(0.1 \pm 0.1 \%)$, kaolinite-chlorite $(0.1 \pm 0.1 \%)$ and palygorskite $(0.02 \pm 0.07 \%)$. Quartz was considered allochthonous because it is not present in the volcanic substrate of the island. Nevertheless, difference of quartz concentration under haze and non-haze conditions were not too far apart (only 10\% higher under haze conditions) to confirm an external and recycled input of this mineral. The mineralogy of aeolian dust and soil samples collected at different altitudes did not vary substantially, reflecting the homogeneity of their source, with both external and local inputs.

Airborne input in soils was inductively estimated through accumulation rates, as well as through the relation between quartz percentages in soils and in aeolian dust samples. The latter method was found to be more accurate. Nevertheless, translocation, leaching and erosion of fine particles in soils became patent in these results.

Finally, the observation of euhedral dolomite crystal in soil samples from the GA plot reflects an edaphic origin, as they do not show evidence of abrasion due to transport.

\section{Acknowledgments}

This study was funded in part through a grant by the University of Las Palmas de Gran Canaria (Project UNI2001/17). We would also like to thank the Secondary Education Institute of the town of San Mateo, the Agricultural Research Centre of the Island Council of Gran Canaria, the Gando Air Force Base (Gran Canaria); and the National Institute of Meteorology of Spain, Gran Canaria Centre, their collaboration and valuable contributions to the present work.

We thank John Roberts for his linguistic review of the paper, and to the Dr. Sergio Castro-Reina, for his linguistic review also and his contributions, that improved the quality of the manuscript. 


\section{References}

Alcántara-Carrió, J., 2003. Dinámica sedimentaria eólica en el istmo de Jandía (Fuerteventura): modelización y cuantificación del transporte. In: Cabildo de Gran Canaria (Ed.), Las Palmas de Gran Canaria, Spain.

Alonso-Zarza, A.M., Silva, P.G., 2002. Quaternary laminar calcretes with bee nest: evidences of smallscale climatic fluctuations, Eastern the Canary Islands, Spain. Palaeogeography Palaeoclimatology 178, 119-135.

Bauer, B.O., Houser, C.A., Nickling, W.C., 2004. Analyses of velocity profile measurements from wind-tunnel experiments with saltation. Geomorphology 59, 81-98.

Capo, R.C., Chadwick, O.A., 1999. Sources of strontium and calcium in desert soil and calcrete. Earth and Planetary Science Letters 170, 61-72.

Capo, R.C., Whipkey, C.E., Blachere, J.R., Chadwick, O.A., 2000. Pedogenetic origin of dolomite in basaltic weathering profile, Lohala peninsula, Hawaii. Geology 28 (3), 271-274.

Carracedo, J.C., Pérez Torrado, F.J., Ancochea, E., Meco, J., Hernán, F., Cubas, C.R., Casillas, R., Rodríguez Bardiola, E., Ahijado, A., 2002. Cenozoic volcanism II: the The Canary Islands. In: Gibbons, W., Moreno, T. (Eds.), The Geology of Spain. The Geological Society, London, pp. 439-472.

Cattle, S.R., Mc Tainsh, G.H., Wagner, S., 2002. Aeolian dust contributions to soil of the Namoi Valley, northern NSW Australia. Catena 47, 245-264.

Cendrero, A., Sánchez, J., Antolín, C., Arnal, S., Díaz de Terán, J.R., Francés, E., Martínez, V., Moñino, M., Nieto, M., Nogales, I., Pérez, E., Rios, C., Robles, F., Romero, A., Suárez, C., 1990. Geoscientific maps form planning in semi-arid regions: Valencia and Gran Canaria, Spain. Engineering Geology 29, 291-319.

Criado, C., Dorta, P., 2003. An unusual "blood rain" over the The Canary Islands (Spain). The storm of January 1999. Journal of Arid Environments 55, 765-783.

De Menocal, P., Ortiz, J., Guilderson, T., Adkins, J., Sarnthein, M., Baker, L., Yarusinsky, M., 2000. Abrupt onset and termination of the African Humid Period: a rapid climate responses to gradual insolation forcing. Quaternary Science Review 19, 347-361.

Dentener, F.J., Carmichael, G.R., Zhang, Y., Lelieveld, J., Crutzen, P.J., 1996. Role of mineral aerosol as a reactive surface in the global troposphere. Journal Geophysical Research 101, 22869-22889.

Díaz-Hernández, J.L., Miranda, J.M., 1997. Tasas de acumulación de polvo atmosférico en un área semiárida del entorno mediterráneo occidental. Estudios Geológicos 53, 211-220.

Donghuai, S., Bloemendal, J., Rea, D.K., Zhisheng, A., Vandernberghe, J., Huayu, L., Ruixia, S., Tungsheng, L., 2004. Bimodal grain-size distribution of Chinese Loess, and its paleoclimatic implications. Catena 55, 325-340.

Dorta, P., 1999. Las invasiones de aire sahariano en Canarias. Consejería de Agricultura. In: Pesca y Alimentación del Gobierno de Canarias y Caja Rural de Tenerife (Eds.), Santa Cruz de Tenerife, Canary Islands.

Dorta, P., Gelado, M.D., Cardona, P., Collado, C., Criado, C., Hernández, J.J., Mendoza, S., Siruela, V., Torres, M.E., Curbelo, D., López, P., Rodríguez, E., 2002. Algunas consideraciones sobre la importancia del polvo de origen sahariano en el clima del archipiélago canario y su aporte a las aguas superficiales oceánicas: el episodio de abril de 2002. In: Publicaciones de la AEC (Eds.), El agua y el clima., Palma de Mallorca, pp. 13-24.

Egli, M., Fitze, P., 2001. Quantitative aspects of carbonate leaching of soils with differing ages and climates. Catena 46, 35-62.

Fernandez-Caldas, F., Tejedor, M.L., Quantin, P., 1982. Suelos de regiones volcánicas. Tenerife. Colección Viera y Clavijo IV, Santa Cruz de Tenerife, pp. 250.

Griffin, D.W., Garrison, V.H., Herman, J.R., Shinn, E.A., 2001. African desert dust in the Caribbean atmosphere: microbiology and public health. Aerobiologia 17, 203-213.

Giraudi, C., 2005. Eolian sand in peridesert northwestern Libya and implications for Late Pleistocene and Holocene Sahara expansions. Palaeogeography Palaeoclimatology 218, 161-173.

Goossens, D., 2001. The aeolian dust accumulation curve. Earth Surface Process and Landforms 26, $1213-1219$.

Goossens, D., Offer, Z.Y., 1994. An evaluation of the efficiency of some eolian dust collectors. Soil Technology 7 , $25-35$.

Götze, J., Nasdala, L., Kleeberg, R., Wenzel, M., 1998. Occurrence and distribution of "moganite" in agate/ chalcedony: a combined Micro-Raman, Rietveld, and Cathodoluminiscence study. Contributions to Mineralogy and Petrology 133, 96-105.

Goudie, A.S., Middleton, N.J., 2001. Saharan dust storms: nature and consequences. Earth Science Review 56, 179-204. 
Hamidi, E.M., Colin, F., Michard, B., Boulangé, B., Nahon, D., 2001. Isotopic tracers of the origin of Ca in carbonate crust from the Middle Atlas, Morocco. Chemical Geology 176, 93-104.

Hansen, A., 1993. Bandama: Paisaje y evolución de Bandama. Cabildo Insular de Gran Canaria, Las Palmas de Gran Canaria.

Herrmann, L., Jahn, R., Stahr, K., 1996. Identification and quantification of dust additions in perisaharan soils. In: Guerzoni, S., Chester, R. (Eds.), The Impact of Desert Dust Across the Mediterranean. Kluwer Academic Publishers, Netherlands, pp. 133-151.

Instituto Tecnológico Geominero de España (ITGE), 1992. Mapa Geológico de España escala 1:100.000 1ạ edición (MAGNA), Hoja de la Isla de Gran Canaria (21-21/21-22), I.T.G.E, Serv. Pub. M ${ }^{\mathrm{o}}$ Industria, Madrid.

Jahn, R., Gudmundsson, Th., Stahr, K., 1985. Carbonatisation as a soil forming process on soils from basic pyroclastic fall deposits on the island of Lanzarote, Spain. In: Fernández Caldas, E., Yaalon, D.H. (Eds.), Catena Supplement 7, Volcanic Soils. Gießen, Germany, pp. 87-96.

Kiefert, L., Mc Tainsh, G.H., 1996. Oxygen isotope abundance in the quartz fraction of aeolian dust: implications for soil and ocean sediment formation in the Australasian region. Australian Journal of Soil Research 34 (4), $467-473$.

Kleber, A., 2000. Compound soil horizons with mixed calcic and argillic properties - examples from the northern Great Basin, USA. Catena 41, 111-131.

Knauth, L.P., Brilli, M., Klonoswski, S., 2003. Isotope geochemistry of Caliche developed on Basalt. Geochimica et Cosmochimica Acta 67, 185-195.

Kubilay, N.N., Saydam, A.C., Yemenicioglu, S., Kelling, G., Kapur, S., Karaman, C., Akça, E., 1997. Seasonal chemical and mineralogical variability of atmospheric particles in the coastal region of the Northeast Mediterranean. Catena 28, 313-328.

Leitz, J., Schmincke, H.U., 1975. Miocene-Pliocene sea-level changes and volcanic phases on Gran Canaria (The Canary Islands) in the light of new K/Ar-ages. Palaeogeography Palaeoclimatology 18, 213-239.

Loÿe-Pilot, M.D., Martin, J.M., 1996. Saharan dust input to the Western Mediterranean: an eleven years record in Corsica. In: Guerzoni, S., Chester, R. (Eds.), The Impact of Desert Dust Across the Mediterranean. Kluwer Academic Publishers, Dordrecht, pp. 191-199.

Martín-Pozas, J.M., 1975. Análisis cuantitativo de fases cristalinas por DRX, en Difracción de muestras policristalinas. In: Saja, J.A. (Ed.), Método de Debye-Scherrer. ICE Universidad de Valladolid, Valladolid, Spain.

Marzol, V., 1988. La lluvia, un recurso natural para Canarias, Servicio de publicaciones de la Caja General de Ahorros de Canarias, no. 130 (investigación 32), Las Palmas de Gran Canaria, Gran Canaria.

Mason, J.A., Jacobs, P.M., Greene, R.S.B., Nettleton, W.D., 2003. Sedimentary aggregates in the Peoria Loess of Nebraska, USA. Catena 53, 377-397.

Matthews, M.D., 1991. The effect of pretreatment on size analyses. In: Syvitski J.P.M., (Ed.), Principles, Methods and Application of Particle Size Analyses, pp. 34-42.

McDougall, I., Schmincke, H.-U., 1976. Geochronology of Gran Canaria, Canary Islands: age of shield building volcanism and other magmatic phases. Bulletin Volcanologique 40, 1-21.

Mc Tainsh, G.H., 1980. Harmattan dust deposition in northern Nigeria. Nature 286, 587-588.

Mizota, C., Matsuhisa, Y., 1995. Isotopic evidence for the eolian origin of quartz and mica in soils developed on volcanic materials in the Canary Archipelago. Geoderma 66, 313-320.

Molinaroli, E., Pistolato, M., Rampazzo, G., Guerzoni, S., 1999. Geochemistry of natural and anthropogenic fallout (aerosol and precipitation) collected from the NW Mediterranean: two different multivariate statistical approaches. Applied Geochemistry 14, 423-432.

Naiman, Z., Quade, J., Ratchett, J., 2000. Isotopic evidence for eolian recycling of pedogenetic carbonate and variations in carbonate dust sources throughout the southwest United Sates. Geochimica Cosmochimica Acta 64, 3099-3109.

Nickling, W., 1978. Eolian sediment transport during dust storms: Slims River Valley, Yukon Territory. Canadian Journal of Earth Science 15, 1069-1084.

Nickling, W., 1983. Grain-size characteristics of sediment transported during dust storms. Journal of Sedimentary Petrology 53 (3), 1011-1024.

Offer, Z.Y., Goossens, K., 2004. Thirteen years of aeolian dust dynamics in a desert region (Negev desert, Israel): analysis of horizontal and vertical dust flux, vertical dust distribution and dust grain size. Journal of Arid Environments 57, 117-140.

Owen, P.R., 1964. Saltation of uniform grains in air. Journal of Fluid Mechanics 20 (2), 225-242. 
Pérez-Marrero, J., Llinas, O., Maroto, L., Rueda, M.J., Cianca, A., 2002. Saharan dust storms over the The Canary Islands during winter 1998 as depicted from the advanced very high-resolution radiometer. Deep-Sea Research Part II 49, 3465-3479.

Piqué, A., 2001. Geology of Northwest of Africa. Gebrüder Borntraeger, Berlin.

Prospero, J.M., 1996. Saharan dust transport over the North Atlantic Ocean and Mediterranean: an overview. In: Guerzoni, S., Chester, R. (Eds.), The Impact of Desert Dust Across the Mediterranean. Kluwer Academic Publishers, Netherlands, pp. 133-151.

Pye, K., 1987. Aeolian Dust and Dust Deposits. Academic Press, London.

Rabenhorst, M.C., Wilding, L.P., Girdner, C.L., 1984. Airborne dust in the Edwards plateau region of Texas. Soil Science Society of America Journal 48, 621-627.

Ramanathan, V., Crutzen, P.J., Kiel, J.T., Rosenfeld, D., 2001. Aerosol, climate and the hydrological cycle. Science 294, 2119-2124.

Sánchez J., 1975. Características y distribución de los suelos de la isla de Gran Canaria. Ph. D Thesis, Departamento de Edafología, Universidad de La Laguna, unpublished.

Sánchez, J., Ríos, C., Pérez-Chacón, E., Suárez, C., 1995. Cartografía Potencial del Medio Natural de Gran Canaria, Cabildo Insular de Gran Canaria and Universidad de Valencia, (Eds.), Universidad de Las Palmas de Gran Canaria (Mapas y Memoria).

Sancho, P., de la Cruz, I., Díaz, A., Martin, F., Hernández, F., Valero, F., Albarran, A., 1992. A five years climatology of back trajectories from the Izaña bascline station, Tenerife, The Canary Islands. Atmospheric Environment 26 (6), 1081-1096.

Schmincke, H.U., 1993. Geological Field Guide of Gran Canaria, sixth ed. Pluto Press, Kiel, Germany.

Simonson, R.W., 1995. Airborne dust and its significance to soils. Geoderma 65, 1-43.

Stoorvogel, J.J., Breemen, N.V., Hansen, B.H., 1997. The nutrient input by Harmattan dust to a forest ecosystem in Côte d'Ivoire, Africa. Biogeochemistry 37, 145-157.

Treadwell-Steitz, C., McFadden, L.D., 2000. Influence of parent material and grain size of carbonate coatings in gravelly soils, Palo Duro Wash, New Mexico. Geoderma 94, 1-22.

Vera, J.A., 2004. Geología de España. Sociedad Geológica de España-Instituto Geológico y Minero Español, Madrid.

Walker, P.H., Chartres, D.J., Hutka, J., 1988. The effect of aeolian accessions on soil development on granitic rocks in south-eastern Australia: I. Soil morphology and particle-size distributions. Australian Journal of Soil Research 26, 1-6.

Yaloon, D.H., 1987. Saharan dust and desert loess: effect on surrounding soils. Journal of African Earth Sciences 6 (4), 569-571.

Zhu, X.R., Prospero, J.M., Millero, F.J., 1997. Daily variability of soluble Fe(II) and soluble total Fe in North African dust in the trade winds at Barbados. Journal of Geophysical Research 102, 212997-221305. 